\title{
Effect of Different Crop Establishment Methods on Growth and Yield of Rice under Normal and Delay Sowing Conditions
}

\author{
Deeksha $^{1 *}$, M. Kumar ${ }^{1}$, A. K. Thakur ${ }^{1}$, T. Chandrakar ${ }^{2}$ and D. P. Singh ${ }^{3}$ \\ ${ }^{1}$ Department of Agronomy, ${ }^{2}$ Department of Soil Science \& Agricultural Chemistry, \\ ${ }^{3}$ Department of Agricultural Statistics and Social Science, S. G. College of Agriculture \& \\ Research Station, IGKV, Jagdalpur (C.G.), India \\ *Corresponding author
}

\section{A B S T R A C T}

\begin{tabular}{|l|}
\hline Key w or d s \\
Rice, Normal \\
sowing, \\
Establishment \\
method, Growth \\
and yield
\end{tabular}

A field experiment was conducted during the kharif season 2019 under AICRIP, at Instructional cum Research Farm of Shaheed Gundadhoor College of Agriculture and Research Station, Jagdalpure, Chhattisgarh, to study the "Effect of different crop establishment methods on growth and yield of rice under normal and delay sowing conditions". The rice crop establishment methods treatment drum seeder (D $\left.\mathrm{S}_{1}\right)$ with normal sowing time ( $\mathrm{N} \mathrm{S} \mathrm{T}_{1}$ ) and it was comparable with treatment normal sowing time (N $\mathrm{S} \mathrm{T}_{1}$ ) and line sowing ( $\mathrm{L} \mathrm{S}_{1}$ ) establishment methods recorded higher plant height, dry matter accumulation, leaf area index, crop growth rate, yield attributes and yield. The highest gross return, net return and $\mathrm{B}$ : $\mathrm{C}$ ratio was recorded under treatment drum seeder $\left(\mathrm{D} \mathrm{S}_{1}\right)$ with normal sowing time $\left(\mathrm{N} \mathrm{S} \mathrm{T}_{1}\right)$ which was comparable to normal sowing time (N $\mathrm{S} \mathrm{T}_{1}$ ) and line sowing ( $\mathrm{L} \mathrm{S}_{1}$ ). The highest $\mathrm{N}$ content and uptake was obtained by drum seeder $\left(\mathrm{D} \mathrm{S}_{1}\right)$ with normal sowing time $\left(\mathrm{N} \mathrm{S} \mathrm{T}_{1}\right)$ and it was comparable to normal sowing time (N S T $)_{1}$ ) and line sowing $\left(\mathrm{L} \mathrm{S}_{1}\right)$.

\section{Introduction}

Rice is the basis of lives for millions of people all over the world. Possibly the oldest domesticated grain in rice crop itself which is the staple cereal food crop for billions of people who depend on their incomes to feed their families. Rice cultivation is the most important use of land for food production, which occupies 9 percent of the world's arable land is rice cultivation. Rice generates 21 percent of world's human energy per capita and 15 percent of protein per capital.
Rice calories are especially significant in Asia, particularly among the poor peoples, wherever it represents $40-90 \%$ of the day caloric intake of the world population. Different problems such as lowering water table, scarcity of labour during peak periods, deteriorating soil health require an alternative establishment method to maintain productivity of rice as well as natural resources. Direct seeded rice (DSR), probably the oldest method of crop establishment, is gaining momentum due to its low-input requirement. It offers certain advantages viz., 
it saves labour, requires less water, less drudgery, early crop maturity, low production cost, better soil physical conditions for following crops and less methane emissions, provides better option to be the best fit in different cropping systems. The drum seeding is good alternative method for transplanted system because it reducing labour requirement and performs as good as transplanted rice at many places. However, the drum seeder is becoming very common for wet seeding due to its low initial investment, easy operation and low maintenance. By the process, the standing establishment by this method change with the quality of field preparation, weeds competition, water management and rainfall during the initial period after sowing. Row seeding can also be conducted on germinated seeds but due to the expense and complexity of acquiring instruments, it is done as a small scale. Performing this operation through cheap and easily designed 8-row drum-seeder can to some extent facilitate the process than other methods. Keeping above cited points the experiment entitled "Effect of different crop establishment methods on growth and yield of rice under normal and delay sowing conditions" was conducted,

\section{Materials and Methods}

A field trial was conducted at Instructional cum Research Farm, Shaheed Gundadhoor College of Agriculture and Research Station, Jagdalpur, Chhattisgarh during kharif season of 2019. The experiment was laid out in split plot design with four replication. The main plot were allotted to different date of sowing viz. normal sowing time and delay sowing and sub plot were tested with three establishment methods viz drum seeder, broadcasting method and line sowing were adopted. This variety samaleswari is derived through pedigree method from a cross $\mathrm{R} 310$ $\times \mathrm{R} 3086$ which matures in 105-112 days under direct seeded and 115-120 days under transplanting conditions. Seeds are medium long, slender and has head rice recovery of $64 \%$. It has the yielding ability of 25 to $40 \mathrm{q}$ $\mathrm{ha}^{-1}$ with the average productivity of $36 \mathrm{q} \mathrm{ha}^{-1}$. The experiment site was geographically situated at $17^{\circ} 46^{\prime} \mathrm{N}$ and $20^{\circ} 34^{\prime} \mathrm{N}$ latitudes and $80^{\circ} 15^{\prime}$ and $82^{\circ} 15^{\prime} \mathrm{E}$ longitudes and at an altitude of $550 \mathrm{~m}$ to $760 \mathrm{n}$ above sea level. The soil of the experimental site is characterized as silt loam (fairly leveled) in texture, moderately acidic in reaction with low available nitrogen, high available phosphorus and potassium. During kharif season 2019, a total of $2162.5 \mathrm{~mm}$ rainfall was recorded against the normal rainfall of $1195 \mathrm{~mm}$. With the onset of monsoon, 115.6 $\mathrm{mm}$ of rainfall was received during the $28^{\text {rd }}$ SMW, while the total rainfall received during the month of June was $221 \mathrm{~mm}$. In the month of July, August, September, October, November and December rainfall of 622.5, 582.2, 499.0, 237.8, 5.6 and $5.8 \mathrm{~mm}$ was received, respectively. The evapotranspiration, maximum and minimum temperature and wind velocity range between 0.7 to $8.0,25.3$ to $31.9{ }^{\circ} \mathrm{C}, 11.8-23.4^{\circ} \mathrm{C}$, and 1.2 to $8.0 \mathrm{~km}$ ph respectively.

\section{Results and Discussion}

\section{Growths parameters}

Sowing duration treatment normal sowing time ( $\mathrm{N} \mathrm{S}_{1} \mathrm{~T}_{1}$ ) registered significantly taller plant as compared treatment delay sowing time (D S $\mathrm{T}_{2}$ ) at all the crop growth stages. While, as regard to establishment methods treatment seeding through drum seeder $\left(\mathrm{D} \mathrm{S}_{1}\right)$ recorded significantly taller plant which was at par with treatment line sowing $\left(\mathrm{L} \mathrm{S}_{3}\right)$ at all the observed durations. Dange et al., (2014) observed that the drum seeding method recorded significantly higher plant height in early sowing over broadcasting method. At all the stages significantly highest dry matter 
accumulation was observed under treatment normal sown time ( $\left.\mathrm{N} S \mathrm{~T}_{1}\right)$ over delayed sown time (D $S T_{2}$ ). So for establishment methods, significantly highest dry matter accumulation at all the growth stages noticed under treatment drum seeding (D $\mathrm{S}_{1}$ ) however, it was at par with treatment line sowing $\left(\mathrm{L}_{3} \mathrm{~S}_{3}\right)$. Similar results that the maximum dry matter accumulated in the rice established by drum seeding $\left(507 \mathrm{~g} \mathrm{~m}^{-2}\right)$ but statistically at a par with mechanical transplanting in puddle conditions as reported by Lavanya et al., (2019). The leaf area index increased from $30 \mathrm{DAE}$ to $90 \mathrm{DAE}$, but from $30 \mathrm{DAE}$ to $60 \mathrm{DAE}$ maximum leaf area expansion was noticed than after wards decreased from 60 DAE to 90 DAE. At all the growth stages significantly highest leaf area index observed under treatment normal sown time ( $\mathrm{N} \mathrm{S} \mathrm{T}_{1}$ ) as compared to delay sown time (D $\mathrm{S} \mathrm{T}_{2}$ ). While, as regards establishment methods drum seeder (D $\left.S_{1}\right)$ registered significantly highest leaf area index and it was at par with treatment line sowing $\left(\mathrm{L} \mathrm{S}_{3}\right)$ method at all the observed duration. Similar finding were reported by Annie et al., (2009). At all the growth stage significantly highest plant population observed under treatment normal sown time ( $\mathrm{N} \mathrm{S}_{1}$ ) as compared to delay sown time (D $S T_{2}$ ). As regards establishment methods treatment broadcasting method $\left(\mathrm{B} \mathrm{S}_{2}\right)$ registered significantly highest plant population and it was at par with treatment drum seeder ( $D S_{1}$ ) method at all the observed duration. The plant population was considerable increased under broadcasting method in early sowing condition. After that, it slowly started decreasing at all the growth stages. It was due to high competition for nutrient moisture and sunlight that decreases the population. While, in the remain establishment method there was no much difference between all the growth stages. These results were in agreement with Rana et al., (2012)

\section{Yield attributes}

The data revealed that the treatment normal sowing time $\left(\mathrm{N} \mathrm{S} \mathrm{T}_{1}\right)$ recorded significantly highest no. of panicle (plant ${ }^{-1}$ ) as compare to delay sowing time (D $S T_{2}$ ). As regard to establishment methods seeding through drum seeder $\left(D S_{1}\right)$ recorded significantly highest no. of panicle ( plant $^{-1}$ ) and it was at par with treatment line sowing ( $\left.\mathrm{L} \mathrm{S}_{3}\right)$. Bera et al., (2016) reported that the normal sowing crop had a significantly higher number of panicle. Among sowing time the treatment normal sowing time ( $\mathrm{N} \mathrm{S} \mathrm{T}_{1}$ ) recorded significantly longest panicle as compared to delay sowing time (D $\mathrm{S} \mathrm{T}_{2}$ ). Likewise, as regard to establishment methods significantly longest panicle was registered with treatment drum seeder $\left(D S_{1}\right)$ and it was at par with treatment line sowing ( $\mathrm{L} \mathrm{S}_{3}$ ). Dawadi et al., (2013) reported that the normal sowing time crop had a significantly longest panicle length. Among sowing time the treatment normal sowing time ( $\mathrm{N} \mathrm{S} \mathrm{T}_{1}$ ) registered significantly highest no. of productive tillers (plant ${ }^{-1}$ ) as compare to delay sowing time ( $\mathrm{D} S \mathrm{~T}_{2}$ ). While, as regards to establishment methods seeding through drum seeder (D $\left.S_{1}\right)$ registered significantly highest no. of productive tillers (plant $^{-1}$ ) which was at par with treatment line sowing $\left(\mathrm{L} \mathrm{S}_{3}\right)$.

These results are similar to that Iqbal et al., (2017) reported that the more number of productive tiller $\left(\right.$ plant $^{-1}$ ) could be acquired when it sown at an ideal sowing dates in direct seeded rice. The treatment normal sowing time ( $\mathrm{N} \mathrm{S} \mathrm{T}_{1}$ ) registered significantly maximum test weight as compare to delay sowing time (D S $\mathrm{T}_{2}$ ). While, as regards to establishment methods seeding through drum seeder (D $\left.S_{1}\right)$ recorded significantly maximum test weight and it was at par with treatment line sowing $\left(\mathrm{L} \mathrm{S}_{3}\right)$. 
Table.1 Plant height, dry matter accumulation, leaf area index, plant population, no. of panicle, panicle length and no. of spikeletas influenced by crop establishment methods of rice under normal and delay sowing condition

\begin{tabular}{|c|c|c|c|c|c|c|c|c|c|c|c|c|c|c|c|}
\hline \multirow[t]{2}{*}{ Treatment } & \multicolumn{3}{|c|}{$\begin{array}{c}\text { Plant height } \\
\text { (cm) }\end{array}$} & \multicolumn{3}{|c|}{$\begin{array}{c}\text { Dry matter } \\
\text { accumulation (g) }\end{array}$} & \multicolumn{3}{|c|}{$\begin{array}{c}\text { Leaf area index } \\
\text { (LAI) }\end{array}$} & \multicolumn{3}{|c|}{$\begin{array}{c}\text { Plant population } \\
\left(\mathrm{m}^{-2}\right)\end{array}$} & \multirow{2}{*}{$\begin{array}{c}\text { Number } \\
\text { of } \\
\text { panicle } \\
\left(\text { plant }^{-1}\right)\end{array}$} & \multirow{2}{*}{$\begin{array}{c}\text { Panicle } \\
\text { Length } \\
\text { (cm) }\end{array}$} & \multirow{2}{*}{$\begin{array}{c}\text { Number } \\
\text { of } \\
\text { spikelet } \\
\left(\text { plant }^{-1}\right)\end{array}$} \\
\hline & $\begin{array}{c}\text { 30 } \\
\text { DAE }\end{array}$ & $\begin{array}{c}\text { 60 } \\
\text { DAE }\end{array}$ & $\begin{array}{c}90 \\
\text { DAE }\end{array}$ & $\begin{array}{c}\text { 30 } \\
\text { DAE }\end{array}$ & $\begin{array}{c}\text { 60 } \\
\text { DAE }\end{array}$ & $\begin{array}{c}90 \\
\text { DAE }\end{array}$ & $\begin{array}{c}\text { 30 } \\
\text { DAE }\end{array}$ & $\begin{array}{c}\text { 60 } \\
\text { DAE }\end{array}$ & $\begin{array}{c}90 \\
\text { DAE }\end{array}$ & $\begin{array}{c}\text { 30 } \\
\text { DAE }\end{array}$ & $\begin{array}{c}\text { 60 } \\
\text { DAE }\end{array}$ & $\begin{array}{c}90 \\
\text { DAE }\end{array}$ & & & \\
\hline \multicolumn{16}{|c|}{ Date of sowing } \\
\hline NS T 1 & 29.56 & 73.14 & 102.66 & 3.57 & 23.76 & 29.46 & 0.67 & 2.29 & 2.81 & 122.58 & 121.17 & 117.92 & 8.55 & 24.08 & 62.67 \\
\hline D S T 2 & 20.57 & 39.31 & 54.55 & 1.83 & 7.37 & 9.25 & 0.46 & 1.08 & 0.74 & 92.17 & 89.67 & 87.25 & 6.33 & 18.32 & 37.92 \\
\hline SEm \pm & 0.26 & 0.12 & 0.21 & 0.18 & 0.16 & 0.29 & 0.007 & 0.020 & 0.14 & 1.36 & 0.62 & 0.39 & 0.13 & 0.34 & 3.25 \\
\hline $\mathrm{CD}(\mathrm{P}=\mathbf{0 . 0 5})$ & 1.22 & 0.55 & 0.94 & 0.84 & 0.77 & 1.38 & 0.04 & 0.09 & 0.65 & 6.34 & 2.85 & 1.85 & 0.59 & 1.58 & 15.14 \\
\hline \multicolumn{16}{|c|}{ Method of crop establishment } \\
\hline D S 1 & 25.73 & 56.75 & 79.46 & 3.63 & 21.28 & 26.45 & 0.58 & 1.79 & 2.18 & 68.13 & 67.37 & 62.25 & 7.95 & 22.85 & 57.13 \\
\hline B S 2 & 24.20 & 54.88 & 77.23 & 1.79 & 8.84 & 11.06 & 0.54 & 1.55 & 1.03 & 190.87 & 189.37 & 187.87 & 6.63 & 19.15 & 44.13 \\
\hline L S 3 & 25.28 & 57.03 & 79.13 & 2.68 & 16.57 & 20.56 & 0.57 & 1.72 & 2.09 & 63.13 & 59.50 & 57.63 & 7.74 & 21.60 & 49.63 \\
\hline SEm \pm & 0.16 & 0.29 & 0.18 & 0.22 & 0.26 & 0.28 & 0.007 & 0.020 & 0.12 & 2.18 & 2.27 & 2.46 & 0.27 & 0.39 & 2.53 \\
\hline $\mathrm{CD}(\mathrm{P}=0.05)$ & 0.51 & 0.91 & 0.58 & 0.67 & 0.81 & 0.88 & 0.03 & 0.06 & 0.37 & 6.81 & 7.08 & 7.68 & 0.85 & 1.23 & 7.87 \\
\hline
\end{tabular}

N S T 1= Normal sowing time, D S T 2= Delay sowing time, D S 1= Drum seeder, B S 2= Broadcasting method, L S 3= Line sowing 
Table. 2 No. of seed, no. of productive tillers, test weight, grain yield, straw yield, harvest index, gross return, net return and B : C ratio as influenced by crop establishment methods of rice under normal and delay sowing condition

\begin{tabular}{|c|c|c|c|c|c|c|c|c|c|}
\hline Treatment & $\begin{array}{l}\text { Number } \\
\text { of grain } \\
\left(\text { plant }^{-1}\right)\end{array}$ & $\begin{array}{c}\text { Number of } \\
\text { productive } \\
\text { tillers } \\
\left(\text { plant }^{-1}\right)\end{array}$ & $\begin{array}{c}\text { Test } \\
\text { weight } \\
\text { (g) }\end{array}$ & $\begin{array}{c}\text { Grain } \\
\text { yield } \\
\left(\mathrm{kg} \mathrm{ha}^{-1}\right)\end{array}$ & $\begin{array}{c}\text { Straw } \\
\text { yield } \\
\left(\mathrm{kg} \mathrm{ha}^{-1}\right)\end{array}$ & $\begin{array}{c}\text { Harvest } \\
\text { Index } \\
(\%)\end{array}$ & $\begin{array}{c}\text { Gross } \\
\text { return } \\
\left(000 \mathrm{Rs} \mathrm{ha}^{-1}\right)\end{array}$ & $\begin{array}{l}\text { Net return } \\
\left(000 \mathrm{Rs} \mathrm{ha}^{-1}\right)\end{array}$ & $\begin{array}{l}B: C \\
\text { ratio } \\
\left(\mathbf{R s}^{-1}\right)\end{array}$ \\
\hline \multicolumn{10}{|c|}{ Date of sowing } \\
\hline N S T 1 & 660.83 & 8.52 & 28.15 & 5458.54 & 6610.00 & 45.23 & $99,072.38$ & $57,566.480$ & 1.38 \\
\hline D S T 2 & 358.25 & 5.94 & 25.48 & 4337.06 & 5712.75 & 43.16 & $78,717.76$ & $37,211.860$ & 0.897 \\
\hline SEm \pm & 25.18 & 0.17 & 0.12 & 24.63 & 41.53 & 0.16 & 449.96 & 449.42 & 0.011 \\
\hline $\mathrm{CD}(\mathrm{P}=\mathbf{0 . 0 5})$ & 117.40 & 0.79 & 0.54 & 114.81 & 193.600 & 0.73 & $2,097.53$ & $2,094.95$ & 0.050 \\
\hline \multicolumn{10}{|c|}{ Method of crop establishment } \\
\hline D S 1 & 552.25 & 7.95 & 27.56 & 5022.02 & 6338.00 & 44.08 & $91,149.64$ & $49,643.74$ & 1.19 \\
\hline B S 2 & 446.50 & 6.57 & 25.33 & 4744.16 & 5882.75 & 44.61 & $86,106.44$ & $44,600.54$ & 1.07 \\
\hline L S 3 & 529.87 & 7.16 & 27.55 & 4927.23 & 6263.37 & 43.91 & $89,429.14$ & $47,923.23$ & 1.15 \\
\hline SEm \pm & 24.59 & 0.21 & 0.31 & 69.46 & 58.75 & 0.32 & $1,260.61$ & $1,260.71$ & 0.030 \\
\hline $\mathrm{CD}(\mathrm{P}=0.05)$ & 76.63 & 0.65 & 0.97 & 216.41 & 183.04 & $\mathrm{NS}$ & $3,927.34$ & $3,927.66$ & 0.095 \\
\hline
\end{tabular}

N S T 1= Normal sowing time, D S T 2= Delay sowing time, D S 1= Drum seeder, B S 2= Broadcasting method, L S 3= Line sowing 
Table.3 Nutrient content and uptake as influenced by crop establishment methods of rice under normal and delay sowing condition

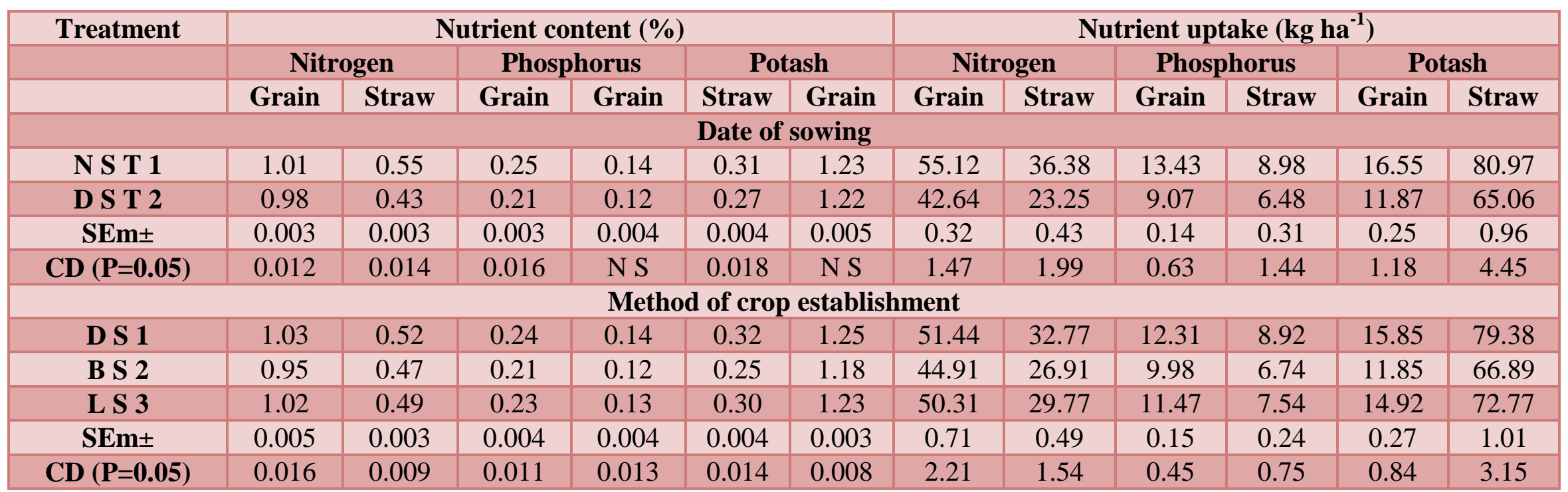

N S T 1= Normal sowing time, D S T 2= Delay sowing time, D S 1= Drum seeder, B S 2= Broadcasting method, L S 3= Line sowing 
Among sowing time the treatment normal sowing time ( $\mathrm{N} \mathrm{S} \mathrm{T}_{1}$ ) registered significantly higher grain yield as compared delay sowing time (D $\mathrm{S} \mathrm{T}_{2}$ ). While, as regard to establishment methods seeding through drum seeder $\left(D S_{1}\right)$ recorded significantly higher grain yield and it was at par with treatment line sowing $\left(L \mathrm{~S}_{3}\right)$. This result are in accordance with the findings in Manjunatha et al., (2009), The treatment normal sowing time (N S $\mathrm{T}_{1}$ ) registered significantly higher straw yield as compare to delay sowing time (D $S$ $\mathrm{T}_{2}$ ). While, as regard to establishment methods seeding through drum seeder $\left(\mathrm{D} \mathrm{S}_{1}\right)$ recorded significantly higher straw yield and it was at par with treatment line sowing (L $\mathrm{S}_{3}$ ). A higher straw yield was recorded in the early planting crop in direct seeded rice which was attributed to a higher dry matter accumulation caused by better nutrient absorption from the soil, and the increased rate of metabolic processes, rate of light absorption and photosynthetic activity as well as more number of tillers. Among sowing time the treatment normal sowing time (N S $\mathrm{T}_{1}$ ) registered significantly highest harvest index as compare to delay sowing time (D S $\mathrm{T}_{2}$ ). The data revealed that establishment methods found non significant for harvest index. Harvest index was not significantly influenced by either of the individual factors nor their interaction.

\section{Economics}

The data indicate that the significantly highest gross return was observed under treatment normal sowing time ( $\mathrm{N} \mathrm{S} \mathrm{T}_{1}$ ) registered as compare to delay sowing time (D $\mathrm{S} \mathrm{T}_{2}$ ). However, the establishment methods seeding through drum seeder (D $S_{1}$ ) recorded significantly highest gross return which was at par with treatment line sowing $\left(\mathrm{L} \mathrm{S}_{3}\right)$. Significantly highest net return was observed under treatment normal sowing time $\left(\mathrm{N} \mathrm{S} \mathrm{T}_{1}\right)$ registered as compare to delay sowing time
(D $\mathrm{S} \mathrm{T}_{2}$ ). However, the establishment methods seeding through drum seeder $\left(D S_{1}\right)$ recorded significantly highest net return and it was at par with treatment line sowing $\left(\mathrm{L} \mathrm{S}_{3}\right)$. The data indicate that the significantly highest B: $C$ ratio was observed under treatment normal sowing time ( $\left.\mathrm{N} \mathrm{S} \mathrm{T}_{1}\right)$ as compare to delay sowing time ( $\mathrm{D} \mathrm{S} \mathrm{T}_{2}$ ). However, the establishment methods seeding through drum seeder $\left(\mathrm{D} \mathrm{S}_{1}\right)$ recorded significantly highest $\mathrm{B}$ : $\mathrm{C}$ ratio which was at par with treatment line sowing $\left(\mathrm{L} \mathrm{S}_{3}\right)$. These results are in accordance to the findings of Gill and Walia (2013).

\section{$\mathbf{N}, \mathbf{P}$ and $\mathrm{K}$ uptake in grain and straw of rice}

The significantly highest $\mathrm{N}$ uptake in grain and straw was observed under treatment normal sowing time ( $\left.\mathrm{N} \mathrm{S} \mathrm{T}_{1}\right)$ as compare to delay sowing time (D $S T_{2}$ ). However, the establishment methods seeding through drum seeder $\left(D S_{1}\right)$ recorded significantly highest $\mathrm{N}$ uptake in grain and straw which was at par with treatment line sowing $\left(\mathrm{L}_{3} \mathrm{~S}_{3}\right)$. The significantly highest $\mathrm{P}$ uptake in grain and straw was observed under treatment normal sowing time ( $\mathrm{N} \mathrm{S}_{1}$ ) as compare to delay sowing time (D $\mathrm{S} \mathrm{T}_{2}$ ). However, the establishment methods seeding through drum seeder $\left(D S_{1}\right)$ recorded significantly highest $P$ uptake in grain and straw which was at par with treatment line sowing $\left(\mathrm{L} \mathrm{S}_{3}\right)$. The significantly highest $\mathrm{K}$ uptake in grain and straw was observed under treatment normal sowing time ( $\mathrm{N} \mathrm{S}_{1}$ ) as compare to delay sowing time (D $\mathrm{S} \quad \mathrm{T}_{2}$ ). However, the establishment methods seeding through drum seeder $\left(D S_{1}\right)$ recorded significantly highest $\mathrm{K}$ uptake in grain and straw which was at par with treatment line sowing ( $\left.\mathrm{L} \mathrm{S}_{3}\right)$. Significantly higher nutrient uptake in direct seeding method as compared to other treatment might be due to the greater and healthy root growth, which increased 
availability, efficient absorption of nutrients from the soil and transport of nutrients from root to shoot and grains. Singh and Singh, (2010) reported that the nutrient uptake was highest with drum seeds, followed by wet seeds and lowest with dry seeds.

In conclusion the rice crop establishment methods treatment drum seeder $\left(\mathrm{D} \mathrm{S}_{1}\right)$ with normal sowing time ( $\left.\mathrm{N} S \mathrm{~T}_{1}\right)$ and it was comparable with treatment normal sowing time ( $\left(\begin{array}{lll}\mathrm{N} & \mathrm{S} & \mathrm{T}_{1}\end{array}\right)$ and line sowing $\left(\begin{array}{ll}\mathrm{L}_{3} & \left.\mathrm{~S}_{3}\right)\end{array}\right.$ establishment method recorded higher plant height, dry matter accumulation, leaf area index, crop growth rate, yield attributes and yield. The treatment drum seeder ( $\mathrm{D} \mathrm{S}_{1}$ ) with normal sowing time ( $\mathrm{N} \mathrm{S} \mathrm{T}_{1}$ ) was comparable to normal sowing time ( $\left.\mathrm{N} \mathrm{S} \mathrm{T}_{1}\right)$ and line sowing $\left(\mathrm{L} \mathrm{S}_{3}\right)$ method which obtained highest profit, time and labour saving. The highest gross return, net return and $\mathrm{B}$ : $\mathrm{C}$ ratio was recorded under treatment drum seeder $\left(D S_{1}\right)$ with normal sowing ( $\mathrm{N} \mathrm{T}_{1}$ ) which was comparable to normal sowing time $\left(\mathrm{N} \mathrm{S} \mathrm{T}_{1}\right)$ and line sowing $\left(\mathrm{L} \mathrm{S}_{3}\right)$. The highest $\mathrm{N}$ content and uptake was obtained by drum seeder (D $\mathrm{S}_{1}$ ) with normal sowing time (N S $\left.\mathrm{T}_{1}\right)$ and it was comparable to normal sowing time (N S $\left.\mathrm{T}_{1}\right)$ and line sowing $\left(\mathrm{L} \mathrm{S}_{3}\right)$.

\section{References}

Annie, P., Swain, P. and Rav, K. S. 2009. Agrophysiological parameter of rice (Oryza sativa) hybrids as affected bydifferent data of planting under costal Orissa. Indian. J. Agric. Sci., 79(1): 25-28.

Bera, P. S., Bandyopadhyay, S., Kundu, C. K., Bandyopadhyay, P. and Pramanick B. 2016. Interaction reaction between different sowing date and weed management methods in drum-seeded Boron rice (Oryza sativa L.). International Journal of Bio-resource and Stress Management, 7(2):206-211.

Dange, A., Sahu, B., Rathore, A. L. and Salam,
D. 2014. Comparative performance of different methods of rice establishments in Kanker district of Chhattisgarh State. Environment \& Ecology, 32 (4): 17481752.

Dawadi, K. P. and Chaudhary, N. K. 2013. Effect of sowing dates and verities on yield and yield attributes of direct seeded rice in chitwan condition. Journal of Agriculture and Environment, Vol : 14.

Gill, J. S and Walia, S. S. 2013 a. Effect of establishment methods on nitrogen levels of basmati rice (Oryza sativa). Indian Journal of Agronomy, 58 (4):506-511.

Iqbal, M. F., Hussain, M. and Rasheed, A. 2017. Direct seeded rice: purely a site specific technology. International Journal of Advanced Research in Biological Sciences, ISSN: 2348-8069.

Lavanya, N. and Reddy, M. M. 2019 b. Yield attributes and quality parameters of rice under different establishment methods and varieties with nitrogen levels under late sown conditions in Telangana state. Journal of Pharmacognosy and Phytochemistry, 8(3): 4185-4192.

Manjunatha, M. V., Masthana Reddy, B. G. and Joshi, V. R. 2009. Performance of rice (Oryza sativa) under different methods of establishment in Tungabhadra canal command, Karnataka. Karnataka Journal of Agricultural Sciences, 22 (5):11511152 .

Rana, I. A., Iqbal, N., Saleem, M. U. and Akhtar, M. 2012. Effect of different planting methods on economic yield and grain quality of rice. International Journal of Applied Agricultural Research, 4(1): 28-34.

Singh, M. and Singh, R. P. 2010. Influence of crop establishment methods and weed management practices on yield and economics of direct seeded rice (Oryza sativa). Indian Journal of Agronomy, 55 (3): 224-229. 


\section{How to cite this article:}

Deeksha, M. Kumar, A. K. Thakur, T. Chandrakar and Singh, D. P. 2021. Effect of Different Crop Establishment Methods on Growth and Yield of Rice under Normal and Delay Sowing Conditions. Int.J.Curr.Microbiol.App.Sci. 10(01): 3165-3173.

doi: https://doi.org/10.20546/ijcmas.2021.1001.369 